\title{
UTILIZATION OF PAPER WASTES FOR CELLULOLYTIC ENZYME PRODUCTION BY ASPERGILLUS NIGER STRAIN 13A AND USING THE BIOORGANIC MATERIALS IN THE BIOCONTROL OF FUSARIUM WILT OF CUCUMBER (CUCUMIS SATIVUS L.)
}

\author{
Belal, E. B. ${ }^{1}$ - Shalaby, M. E. ${ }^{1}$ - El-SAID, R. A. R. ${ }^{2}$ - ABDELRAZEK, M. A. S. ${ }^{3}$ - EBRAHIM, A \\ E. E. ${ }^{2 *}-\mathrm{GAD}, \mathrm{W} . \mathrm{A}^{4}$ \\ ${ }^{I}$ Agricultural Botany Department, Agricultural Microbiology, Faculty of Agriculture, \\ Kafrelsheikh University, Kafr El-Sheikh, Egypt \\ ${ }^{2}$ Biological and Ecological Department, Faculty of Home Economic, Al-Azhar University, \\ Tanta, Egypt \\ ${ }^{3}$ Department of Chemistry and Toxicity of Pesticides, Faculty of Agriculture, Kafrelsheikh \\ University, Kafr El-Sheikh, Egypt \\ ${ }^{4}$ Central Laboratory, Kafr El-Sheikh Company for Water and Wastewater, Kafr El-Sheikh, \\ Egypt \\ *Corresponding author \\ e-mail: alzahraa_ibrahim16@yahoo.com; phone: +20-10-2053-2190
}

(Received $15^{\text {th }}$ Sep 2020; accepted $21^{\text {st }}$ Dec 2020)

\begin{abstract}
The main purpose of this study is maximizing the utilization of paper waste material and decrease its harmful effect. Eleven fungal isolates were selected and tested to assess their cellulolytic potential. The isolates13A which were isolated from immature compost showed the highest Cellulolytic Index values $0.47 \mathrm{~mm}$. According to the morphological characteristics and the 18S rRNA gene sequence, the isolate13A was identified as Aspergillus niger strain13A. The effect of $\mathrm{pH}$ and temperature on growth of Aspergillus niger strain13A and its production of cellulase were investigated, the optimal culture conditions was recorded at $\mathrm{pH} 6.0$ after 6 days of incubation at $35^{\circ} \mathrm{C}$. Under optimal conditions various paper waste materials were used for enzyme production under submerged and solid-state fermentation. Maximum production of cellulase by Aspergillus niger strain13A was shown using kraft brown bags and cardboard under solid state fermentation. Aspergillus niger strain13A exhibited also good degradability for a mixture of kraft, cardboard, foolscap and printout paper, under solid state fermentation resulting in the production of bioorganic material. Results of this study showed that treatment of soil with bioorganic materials demnstrarting high effectiveness in controlling Fusarium wilt of cucumber (Cucumis sativus L.) could be considered as promising alternative to chemical fungicides.
\end{abstract}

Keywords: waste paper, cellulase, solid-state fermentation, Aspergillus niger, biological control

\section{Introduction}

In recent years, solid wastes (MSW) generated by industrial, commercial, domestic and agricultural activities, have become serious environment issues (Joshi et al., 2017). Among all solid waste, waste paper represents $10-39 \%$ of global solid waste, where the annual world output of these wastes is nearly 400-1000 million tons per year (Edjabou et al., 2015; Neelamegam et al., 2018; Ozola et al., 2019). Paper waste is defined as waste generally comprised of newspaper, printout paper, packing paper, advertising paper, newspaper and cardboard (Fonoll et al., 2016). Almost all waste paper, especially 
in developing countries, is usually disposed of by landfilling or incineration leading to the formation of leachate and greenhouse gases causing more environmental pollution and loss of cellulose resources (Saferi and Yusof, 2013; Su et al., 2017). As renewable and abundant resources, many reports have been focused on the conversion of paper waste into value-added products such as bioethanol, cellulase enzymes and mixed with other organic materials for co-composting (Fonoll et al., 2016).

Paper products are made from fibers of plant origin, especially wood. Paper wastes materials are mainly composed of cellulose 40-80\%, hemicellulose 5-15\% and slight amounts of lignin (Sun and Cheng, 2002). This rich content of cellulose gives these wastes a significant potential as cheaper fermentation substrates for cellulase production compared with avicel and carboxymethylcellulose. Enzymatic hydrolysis of cellulose in waste paper produces glucose, which is also used in the biofuel production process ( $\mathrm{Wu}$ and Cheng, 2005; Zapata et al., 2018).

In nature, cellulolytic microorganisms play an important role in biodegradation process of lignocellulosic materials. Cellulase enzymes belong to the glycoside hydrolase family and are capable of hydrolyzing cellulose materials and related oligosaccharides into glucose and other monoproducts (Lynd et al., 2002; Peciulyte, 2007; Sukharnikov et al., 2012). This multi-enzyme complexes, include three enzymes, namely: endo-1,4- $\beta$-D-glucanase, EC 3.2.1.4 (CMCase), exo-1,4- $\beta$-D-glucanase, EC 3.2.1.91 (cellodextrinase), $\beta$-glucosidase, EC 3.2.1.21 (cellobiase) (Dashtban et al., 2009). Cellulolytic enzymes are the third largest industrial enzymes worldwide due to their applications in many industrial fields such as food, paper and pulp, textile and detergent industry, feed additives paper recycling, waste water treatment, organic acids, bio-ethanol, etc.

The main problem for industrial application of this enzyme is the high- cost and low yield of the production. Therefore, the use of low-cost fermentation technologies as well as developing hyper producing microbial strains to utilize cheaper substrates can help to reduce the production cost as well as to achieve environmental sustainability (Kurup et al., 2005; Singhania, 2009). Several microorganisms can use lignocellulosic wastes as their growth medium to produce cellulolytic enzymes. Filamentous fungi are generally known to be a good source for cellulases due to their ability of decomposing lignocellulose materials, extracellular release, higher yields production of enzymes compared to other microbes and ability to produce complete enzyme complex (Lee and Koo, 2001). Many fungal species including Aspergillus sp, Trichoderma sp and Penicillium sp. (Bansal et al., 2012; Prasanna et al., 2016; Ellilä et al., 2017) are used to produce cellulolytic enzymes especially Aspergillus ornatus (Toor and Ilyas, 2014), Aspergillus niger and Rhizopus sp. (Baig and Saleem, 2012; Santos et al., 2016). Fungal production of cellulases is carried out by both submerged fermentation (SmF) and solid state (SSF) fermentation (Bansal et al., 2012; Lodha et al., 2020).

F. oxysporum is a soil-borne plant pathogen, accountable for vascular wilts in a wide range of economical plants, this disease spreads widely and takes place, nearly all the cucumber plant regions in the world. Fusarium wilt has already become one of the most destructive diseases in commercial production of cucumber (Ye et al., 2004).

Biological control using antagonistic microbes to minimize the use of chemicals has become important in recent years (Khan and Khan, 2001).

This study is focused on bio-utilization of paper wastes for cellulolytic enzyme production using submerged and solid-state fermentation techniques as well as using the bioorganic materials in controlling Fusarium wilt of cucumber (C. sativus L.). 


\section{Materials and methods}

\section{Media}

The following media were used: Czapek's dox medium (CDA), potato dextrose agar (PDA) and potato dextrose without agar (PDB) (Nasr et al., 2011), mineral salt medium (MSl) described by Cunha et al. (2012) and contained (w/v): $0.14 \%\left(\mathrm{NH}_{4}\right)_{2} \mathrm{SO}_{4}, 0.20 \%$ $\mathrm{KH}_{2} \mathrm{PO}_{4}, 0.03 \% \mathrm{CaCl}_{2}, 0.02 \% \mathrm{MgSO}_{4} 7 \mathrm{H}_{2} \mathrm{O}, 0.50 \%$ peptone, $0.20 \%$ yeast extract, $0.03 \%$ urea, $0.10 \%$ Tween 80 , and $0.10 \%$ of salt solution $\left(5 \mathrm{mg} / \mathrm{L} \mathrm{FeSO} 77 \mathrm{H}_{2} \mathrm{O}, 1.6\right.$ $\mathrm{mg} / \mathrm{L}, \mathrm{MnSO}_{4} \mathrm{H}_{2} \mathrm{O}, 1.4 \mathrm{mg} / \mathrm{L} \mathrm{ZnSO}_{4} 7 \mathrm{H}_{2} \mathrm{O}$, and $2.0 \mathrm{mg} / \mathrm{L} \mathrm{CoCl}_{2}$ ) and mineral salt medium $+1.5 \%$ agar (MSA). All media are of high chemical purity products of DIFCO, Becton Dickinson and Company, USA.

\section{Selection and preparation of raw material}

Newspaper, coated cardboard, kraft brown bags, corrugated cardboard, foolscap and A4 printout paper sheets of $80 \mathrm{~g}$ were selected for the cellulase production and these wastes were collected from the different areas of Kafr El-Sheikh Governorate: Kafr ElSheikh University Colleges, houses and supermarkets. All wastepaper material and Whatman No. 1 filter paper were cut into small pieces and dried in a hot-air oven to reduce the moisture content; substrates were then milled to obtain the powder form.

\section{Sample collection}

Isolation samples of $500 \mathrm{~g}(\mathrm{ml})$ were collected in sterile plastic containers from two localities which serve as their natural habitat for cellulose-degrading fungi, four samples were obtained from Kafr El-Sheikh University farms: (A1) mature compost, (A2) immature compost, (A3) cow dung and (A4) old degraded tree. As well as three samples, (B1) primary effluent mud (B2) wastewater from the sedimentation reservoir, (B3) paper wastes were collected from the paper factory located in Tanta city - Gharbia Governorate in Egypt as shown in Figure 1.

\section{Isolation, purification and screening of cellulolytic fungi}

Isolation was performed by serial dilution method, $100 \mu \mathrm{l}$ of each dilution was spread on plates containing MSA medium supplemented with $1 \%$ carboxymethyl cellulose (CMC) as a sole source of carbon and incubated at room temperature for 4 days. Morphologically dissimilar single fungal colonies were isolated and further purified by repeated culturing on the same media to obtain a pure culture and then stocked at $4{ }^{\circ} \mathrm{C}$ on PDA slant in refrigerator for further studies.

Cellulolytic isolates were screened by clearance test using Congo red staining method as described by Teather and Wood (1982). Cellulolytic fungal isolates were selected on the basis of the diameter of the clear zone surrounding the colonies, hydrolysis zone could be observed only around colonies of the active fungal isolates. Cellulolytic activity on CMC agar was recorded as the Cellulolytic Index (CI) which was recorded as hydrolysis ratios $=$ clear zone diameter $/$ growth diameter (Khokhar et al., 2012).

\section{Identification}

All selected fungal isolates were identified on the basis of morphological characteristics. Mycelia morphology characteristics such as surface appearance, texture, reverse and pigmentation were determined on the CDA and PDA plates after incubation 
at $25{ }^{\circ} \mathrm{C}$ for 4 and 7 days. Microscopic characterization, spore shape, color and conidiophores shape were examined under light microscope.

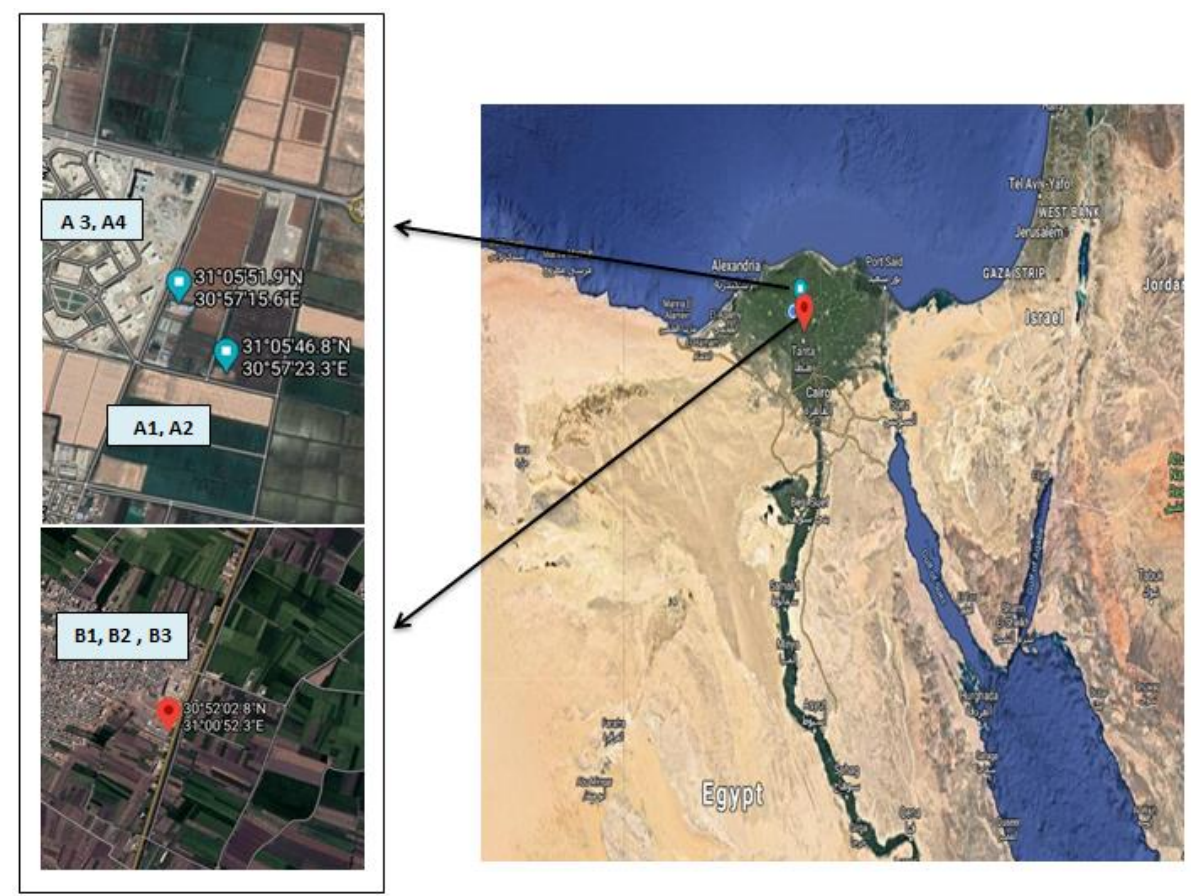

Figure 1. The sampling location: A1, A2, A3 and A4 at Kafr El-Sheikh University farms. B1, B2 and B3 at Tanta city - Gharbia Governorate in Egypt

The efficient cellulolytic fungus identification encoded 13A was completed according to molecular biology techniques. For molecular identification, fungal mycelium from a 3 days old culture in potatoes dextrose broth (PDB) was harvested using Whatman No. 1 filter paper. The total genomic DNA was extracted using CTAB protocol (Benito et al., 1993). DNA of the fungal isolate was amplified by polymerase chain reaction (PCR) at Sigma Scientific Services. The identification was achieved by comparing the contiguous DNA sequence with data from the reference and type strains available in public databases of Gen Bank using the BLAST program (National Centre for Biotechnology Information). (http://www.ncbi.nlm.nih.Gov/BLAST). The obtained nucleotide sequences were aligned using ARB to construct the phylogenetic tree using the neighbor-joining method based on Jukes Cantor Model and the isolate was registered in Gen Bank (Eida et al., 2018).

\section{Effect of $p H$ and temperature on A. niger strain $13 A$ growth and cellulases production}

Production of cellulolytic enzymes was performed by $\mathrm{SmF}$ method in a $250 \mathrm{~mL}$ Erlenmeyer flasks. All flask contained $100 \mathrm{ml}$ of MSL medium supplemented with 1\% carboxymethyl cellulose as a sole source of carbon. After sterilizing medium was inoculated with $3 \mathrm{ml}$ of $1 \times 10^{6} \mathrm{~A}$. niger strain 13A spore suspension. To determine the optimum $\mathrm{pH}$ the experiment was carried out at $\mathrm{pH}$ levels $(4,5,6,7$ and 8), and the culture was incubated at room temperature for 6 days. Optimal temperature was 
determined by adjusting MSL medium at $\mathrm{pH} 6.0$ and incubating cultures at different temperature values $\left(20,25,30,35,40,45\right.$ and $\left.50{ }^{\circ} \mathrm{C}\right)$ for 6 days.

\section{Bio-utilization of different paper waste materials}

The production of cellulolytic enzymes using waste paper was carried out at the optimal fermentation parameters under Smf and SSF. For SmF, fifty ml of MSL medium was applied containing $1 \%$ from each prepared raw-material or CMC as a control. SSF was carried out in fermentation medium, containing $5 \mathrm{~g}$ of each prepared raw-material or Whatman No. 1 filter paper as a control, moistened with $7.5 \mathrm{ml}$ nutrient salt solution. All flasks were inoculated with $3 \mathrm{ml}$ of $1 \times 10^{6}$ fungus spore suspension and incubated at $35^{\circ} \mathrm{C}$ for 14 days.

\section{Enzyme extraction}

For extraction of cellulases in the SmF process, fungal cultures were filtered through a two layered woven gauze, while in SSF the enzyme was extracted by adding $50 \mathrm{~mL}$ of $0.05 \mathrm{M}$ citrate buffer ( $\mathrm{pH} 4.8$ ) on SSF culture-flasks and shaken at $120 \mathrm{rpm}$ for $1 \mathrm{~h}$ to separate and suspend the extracellular enzymes in the buffer. The whole contents were then filtered as in the case of SmF. The culture filtrate thus obtained was centrifuged for $20 \mathrm{~min}$ at $7000 \mathrm{rpm}$ to separate the biomass, and the supernatant was analyzed to determine the cellulolytic productivity (Imran et al., 2017).

\section{Analytical methods}

FP-ase and CMC-ase activities were determined using IUPAC methods as described by Ghose (1987). Reducing sugar concentration was estimated by dinitrosalicylic acid (DNS) method using glucose as the standard (Miller, 1959).

\section{Estimation of fungal growth}

The mycelial dry weight of biomass ( $\mathrm{g}$ ) was determined by washing the fungal filtrate mycelium and biomass pellet obtained from centrifugation process and drying it at $80^{\circ} \mathrm{C}$ for $24 \mathrm{~h}$ (Belal, 2003).

\section{Assay of biocontrol agents}

A. niger strain 13A was evaluated for their ability to inhibit Fusarium oxysporum in dual culture as described by Martyn and Stack (1990) and Tapwal et al. (2005). The radial mycelial growth of the pathogen was recorded after 10 days of incubation and inhibition percent in mycelial growth was calculated as: inhibition Percent $=$ Control Treatment / Control $\times 100$.

\section{Biodegradation of paper wastes mixture to produce biomass (bioorganic materials) for the suppression of Fusarium wilt of cucumber}

Dry-milled paper wastes, kraft brown bags, cardboard, foolscap and printout paper were mixed well with ratio of 1:1:1:1 and placed in two glass boxes. This mixture was moistened in a ratio of $1 \mathrm{~g}: 3 \mathrm{ml}$ of MSL medium without the addition of any carbon source, as well as moistened when needed under sterile conditions. One of the two boxes was treated with $1 \times 10^{6}$ spore suspension of $A$. niger strain $13 \mathrm{~A}$ while the other was not treated. The two boxes were incubated at the optimal growth conditions for 42 days, on 
the other hand, the produced biomass (bioprorganic materials) was used for soil treatment (at a rate of 2\%) for controlling Fusarium wilt of cucumber (Cucumis sativus L.) (Belal, 2008). Soil was inoculated with Fusarium oxysporum, as described by Belal et al. (1996).

\section{Calculation of the infection severity}

The incidence and the severity of the disease were calculated according to Ahmed (2010) from the beginning of the disease symptoms on the studied plants weekly after 17 days of planting until the end of the study (45 days).

\section{Statistical analysis}

All experiments were carried out using completely randomized design and data were analyzed by one-way analysis of variance (ANOVAs), except for bio-utilization of different paper waste materials experiment was analyzed by two-way analysis of variance (ANOVAs). The means comparison was done using Duncan's multiple range test and least significant difference (LSD) at $\mathrm{P} \leq 0.05$. All statistical calculations were carried out using statistical program, SPSS, version, 20.

\section{Results and discussion}

\section{Isolation and screening of fungi with cellulolytic production}

Seven samples were collected from different locates for the isolation of highly efficient cellulose degrading fungi. Twenty-three fungal strains were isolated, out of which 11 fungal isolates were selected based on morphological dissimilarities and tested to assess the celluloes-hydrolisis ability on MSA medium containing 1\% CMC as sole carbon source as tabulated in Table 1. All tested isolates showed Cellulolytic Index (CI) ranging from 0.0 to $0.47 \mathrm{~mm}$. High CI values of $0.47 \mathrm{~mm}$ was showed by the isolate encoded 13A which was isolated from immature compost. this isolate was selected as a potential cellulase producing isolate for further studies.

Table 1. Hydrolysis ratio of carboxymethycellulose (CMC) by fungal genera incubated at $25^{\circ} \mathrm{C}$ for 4 days

\begin{tabular}{c|c|c|c|c|c}
\hline \multirow{2}{*}{ Isolation source } & Fungal genera & $\begin{array}{c}\text { Growth } \\
\text { diameter }(\mathbf{m m})\end{array}$ & $\begin{array}{c}\text { Growth } \\
\text { diameter + clear } \\
\text { zone }(\mathbf{m m})\end{array}$ & $\begin{array}{c}\text { Clear zone } \\
(\mathbf{m m})\end{array}$ & CI \\
\hline \multirow{2}{*}{ Wastewater } & Penicillium $\mathrm{sp}$ & 20.33 & 26.66 & 6.33 & $0.31^{\mathrm{b}}$ \\
\hline \multirow{2}{*}{ Degraded tree } & Trichoderma $\mathrm{sp}$, & 77.00 & 90.00 & 13.0 & $0.17^{\mathrm{d}}$ \\
\cline { 2 - 6 } & Cladosporium $\mathrm{sp}$ & 30.33 & 35.33 & 5.00 & $0.16^{\mathrm{d}}$ \\
\hline Primary effluent mud & Penicillium $\mathrm{sp}$ & 18.00 & 20.00 & 2.00 & $0.11^{\mathrm{d}}$ \\
\hline \multirow{2}{*}{ Mature compost } & Fusarium $\mathrm{sp}$ & 29.66 & 42.33 & 10.7 & $0.34^{\mathrm{b}}$ \\
\cline { 2 - 6 } & Trichoderma $\mathrm{sp}$, & 71.88 & 90.00 & 18.1 & $0.25^{\mathrm{b}}$ \\
\hline \multirow{2}{*}{ Immaper wastes } & Rhizopus sp. & 90.00 & 90.00 & 00.0 & $0.00^{\mathrm{e}}$ \\
\hline \multirow{2}{*}{ Cow dung } & Aspergillus niger & $\mathbf{6 1 . 3 3}$ & $\mathbf{9 0 . 0 0}$ & $\mathbf{2 8 . 7}$ & $\mathbf{0 . 4 7 ^ { \mathrm { a } }}$ \\
\cline { 2 - 6 } & Aspergillus flavus & 88.33 & 90.00 & 1.67 & $0.02^{\mathrm{e}}$ \\
\cline { 2 - 6 } & Mucor sp. & 90.00 & 90.00 & 00.0 & $0.00^{\mathrm{e}}$ \\
\hline
\end{tabular}

Values having the same letter within a column are not significantly different according to Duncan multiple range test $(\mathrm{P} \leq 0.05)$. Bold values indicate the highest Cellulolytic Index 


\section{Identification}

All selected isolates were preliminary classified based on the morphological and the microscopical characteristics. Eleven isolates were identified as Trichoderma sp, Penicillium sp., Rhizopus sp., Mucor sp., Aspergillus niger, Fusarium sp. Aspergillus sp. Cladosporium sp, Aspergillus flavus, Penicillium sp. and Alternaria sp. Fungi are known to excrete a large number of cellulolytic enzymes for commercial production (Imran et al., 2016).

The most efficient isolate $13 \mathrm{~A}$ was confirmed and identified based on molecular approach following $18 \mathrm{Sr}$ DNA sequencing. This isolate was found to be closely similar to Aspergillus niger, thus identified as A. niger. This sequence has been recorded in NCBI GenBank with an accession No. SFC101821 with the name of A. niger strain 13A. Phylogenetic tree showed in Figure 2 was constructed by neighbor-joining method using nucleotide evolutional model based on synonymous and non-synonymous nucleotide substitutions. Aspergillus niger is known to be a good producer of cellulolytic enzymes perhaps due to its high cellulase productivity and safe use in industry. Our results are in agreement with previous findings of researchers, such as Juhasz et al. (2003) and Abdullah et al. (2016). Therefore, Aspergillus niger strain 13A was selected as efficient producer for extracellular cellulases for further studies.

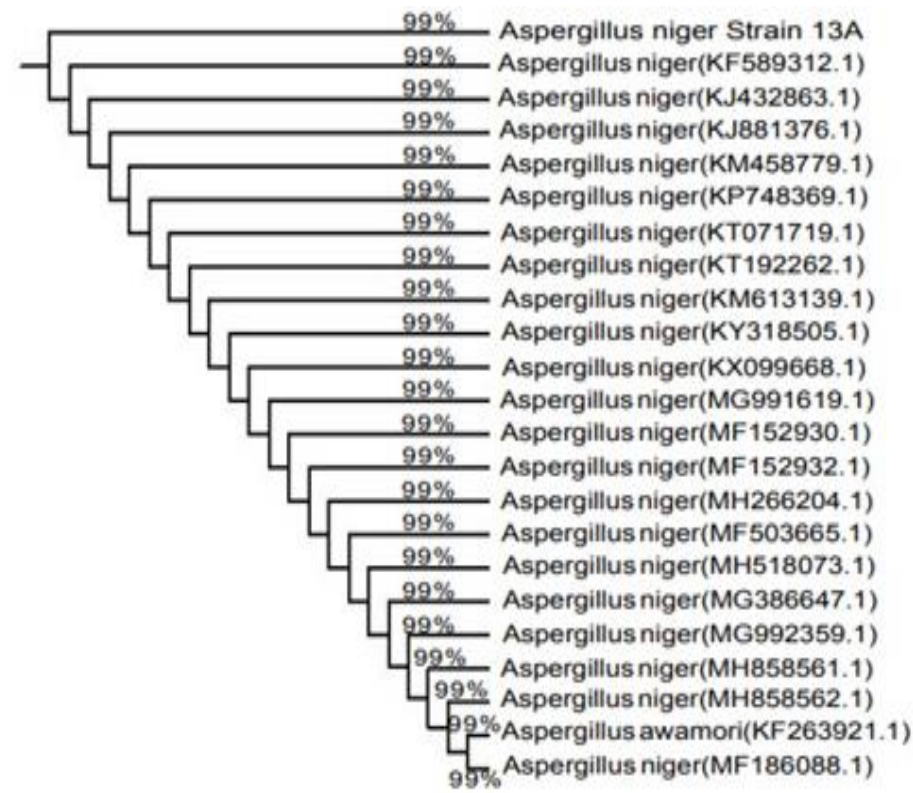

Figure 2. Phylogenetic tree derived from 18S ribosomal DNA gene sequence of Aspergillus niger (SFC101821) and sequences of the closest phylogenetic neighbors obtained by NCBI BLAST

\section{Effect of $\mathrm{pH}$ and temperature on A. niger strain $13 A$ growth and cellulases production}

Environmental factors have an important influence on the microbial growth, production activity and their degradation ability of organic material. Factors like $\mathrm{pH}$ and temperature, have an important effect on the microbial degradation of paper wastes and so these conditions must be considered when the biodegradability of paper wastes is tested (Belal, 2008) therefore temperature and $\mathrm{pH}$ factors were optimized to determine the optimal conditions for growth and maximum levels of cellulase production. 


\section{Optimum pH}

The effect of $\mathrm{pH}$ on A. niger strain 13A growth and their cellulase production is shown in Table 2. Generally, the obtained results showed that the optimum $\mathrm{pH}$ for $A$. niger strain 13A was $\mathrm{pH}$ 6.0. The maximum mycelial dry weight was $0.37 \pm 0.026 \mathrm{~g} / 100 \mathrm{ml}$ as well as the maximum production of CMC-ase and FP-ase were $1.24 \pm 0.049$ and $0.27 \pm 0.025 \mathrm{IU} / \mathrm{ml}$ respectively. Fungus growth and FP-ase production showed stability at $\mathrm{pH}$ 6.0-7.0, a further increase in the optimal $\mathrm{pH}$ decreased the growth and cellulase productivity. The enzyme production reduced drastically at $\mathrm{pH} 9.0$, this decreasing at higher $\mathrm{pH}$ may be due to proteolytic inhibition of the cellulase. slightly acidic $\mathrm{pH}$ is preferred for cellulase production by A. niger (Dutt and Kumar, 2014).

Table 2. Effect of $p H$ on A. niger strain $13 A$ growth and cellulase production

\begin{tabular}{c|c|c|c}
\hline $\mathbf{p H}$ & Mycelial dry weight $(\mathbf{g} / \mathbf{1 0 0} \mathbf{~ m l})$ & CMC-ase $\mathbf{I U} / \mathbf{m l}$ & FP-ase IU/ml \\
\hline 4.0 & $0.21 \pm 0.02^{\mathrm{c}}$ & $0.82 \pm 0.018^{\mathrm{d}}$ & $0.13 \pm 0.01^{\mathrm{c}}$ \\
5.0 & $0.32 \pm 0.025^{\mathrm{a}}$ & $1.07 \pm 0.074^{\mathrm{b}}$ & $0.18 \pm 0.042^{\mathrm{b}}$ \\
6.0 & $0.37 \pm 0.026^{\mathrm{a}}$ & $1.24 \pm 0.049^{\mathrm{a}}$ & $0.27 \pm 0.025^{\mathrm{a}}$ \\
7.0 & $0.29 \pm 0.35^{\mathrm{b}}$ & $0.94 \pm 0.011^{\mathrm{c}}$ & $0.25 \pm 0.026^{\mathrm{a}}$ \\
8.0 & $0.20 \pm 0.025^{\mathrm{c}}$ & $0.36 \pm 0.093^{\mathrm{e}}$ & $0.15 \pm 0.093^{\mathrm{c}}$ \\
9.0 & $0.13 \pm 0.021^{\mathrm{d}}$ & $0.04 \pm 0.028^{\mathrm{f}}$ & $0.08 \pm 0.041^{\mathrm{d}}$ \\
\hline
\end{tabular}

Values having the same letter within a column are not significantly different according to Duncan multiple range test $(\mathrm{P} \leq 0.05)$

\section{Optimum temperature}

The influence of different temperatures on A. niger strain 13A growth and their cellulase production is shown in Table 3. The highest yield of mycelial dry weight $(0.51 \pm 0.025 \mathrm{~g} / 100 \mathrm{ml})$ as well as the maximum productivity of CMC-ase $(1.21 \pm 0.041 \mathrm{IU} / \mathrm{ml}) \mathrm{FP}$-ase $(0.44 \pm 0.060 \mathrm{IU} / \mathrm{ml})$ was obtained when $A$. niger strain $13 \mathrm{~A}$ was grown at $35^{\circ} \mathrm{C}$ and the initial $\mathrm{pH}$ was 6.0. An increase in incubation temperature to $35{ }^{\circ} \mathrm{C}$ decrease fungus growth and enzyme production. Our results are in agreement with previous findings of researchers, such as Sohail et al. (2009) and Nasr et al. (2011) who reported that the optimum temperature for cellulase production by the fungus might lie between 27 and $35^{\circ} \mathrm{C}$. The decrease of cellulase production levels at lower temperature may be due to the depressed transport of cellulose across the cells, causing reduced yield of cellulase production (Dutt and Kumar, 2014).

\section{Bio-utilization of different paper waste materials}

Aspergillus niger strain 13A was used under the optimal growth conditions with the aim of utilization of paper waste materials as a sole carbon source for cellulase production under submerged (SmF) and solid-state fermentation (SSF).

The obtained results were illustrated in Figure 3; the general trend of substrate degradation with $A$. niger strain $13 \mathrm{~A}$ under both of SmF and SSF was CMC (SmF control) $>$ filter paper $\quad(\mathrm{SSF} \quad$ control $)>\mathrm{kraft}$ brown bags $>$ cardboard $>$ foolscap $>$ printout paper $>$ newspapers and coated cardboard. The highest production of cellulase by A. niger strain $13 \mathrm{~A}$ was obtained by using kraft 
brown bags as a carbon source in both SSF (CMC-ase was $0.813 \pm 0.067 \mathrm{IU} / \mathrm{ml}$, FP-ase was $0.25 \pm 0.05 \mathrm{IU} / \mathrm{ml}$ ) and $\mathrm{SmF}(\mathrm{CMC}$-ase was $0.36 \pm 0.11 \mathrm{IU} / \mathrm{ml}$, FP-ase was $0.090 \pm 0.02 \mathrm{IU} / \mathrm{ml})$. As well as cardboard substrate gave the highest cellulase production in both SSF (CMC-ase was $0.72 \pm 0.016 \mathrm{IU} / \mathrm{ml}$, FP-ase was $0.24 \pm 0.017 \mathrm{IU} / \mathrm{ml}$ ) and $\mathrm{SmF}$ (CMC-ase was $0.43 \pm 0.076 \mathrm{IU} / \mathrm{ml}$, FP-ase was $0.16 \pm 0.008 \mathrm{IU} / \mathrm{ml})$. On the other hand, newspaper and coated cardboard exhibited the lowest enzyme production.

Table 3. The effect of temperature on A. niger strain 13A growth and cellulase production

\begin{tabular}{c|c|c|c}
\hline $\begin{array}{c}\text { Temperature } \\
\left({ }^{\circ} \mathbf{C}\right)\end{array}$ & Mycelial dry weight $(\mathbf{g} / \mathbf{1 0 0 m l})$ & CMC-ase IU/ml & FP-ase IU/ml \\
\hline 20 & $0.32 \pm 0.021^{\mathrm{d}}$ & $0.40 \pm 0.028^{\mathrm{f}}$ & $0.08 \pm 0.05^{\mathrm{e}}$ \\
25 & $0.39 \pm 0.020^{\mathrm{cb}}$ & $0.54 \pm 0.026^{\mathrm{e}}$ & $0.23 \pm 0.012^{\mathrm{c}}$ \\
30 & $0.42 \pm 0.034^{\mathrm{b}}$ & $0.93 \pm 0.057^{\mathrm{c}}$ & $0.36 \pm 0.021^{\mathrm{b}}$ \\
35 & $0.51 \pm 0.025^{\mathrm{a}}$ & $1.21 \pm 0.041^{\mathrm{a}}$ & $0.44 \pm 0.060^{\mathrm{a}}$ \\
40 & $0.46 \pm 0.036^{\mathrm{b}}$ & $1.09 \pm 0.015^{\mathrm{b}}$ & $0.26 \pm 0.039^{\mathrm{c}}$ \\
45 & $0.26 \pm 0.047^{\mathrm{e}}$ & $0.61 \pm 0.032^{\mathrm{d}}$ & $0.15 \pm 0.092^{\mathrm{d}}$ \\
50 & $0.22 \pm 0.031^{\mathrm{e}}$ & $0.33 \pm 0.026^{\mathrm{g}}$ & $0.006 \pm 0.065^{\mathrm{e}}$ \\
\hline
\end{tabular}

Values having the same letter within a column are not significantly different according to Duncan multiple range test $(\mathrm{P} \leq 0.05)$

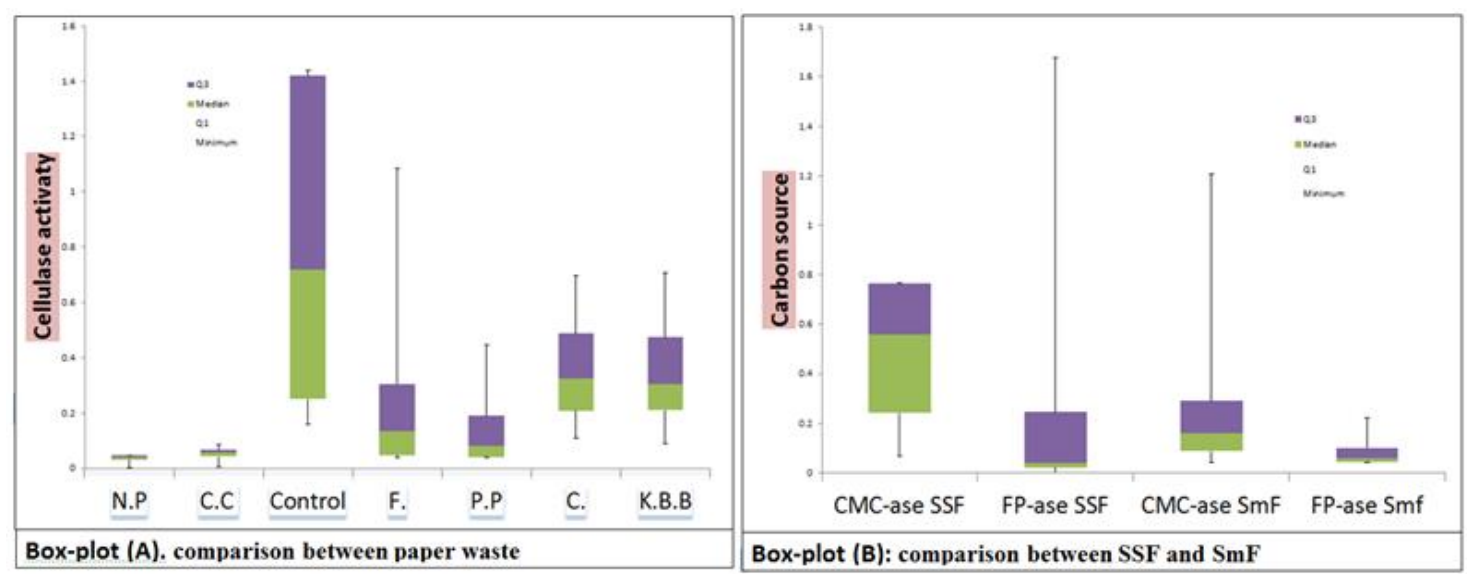

Figure 3. Using paper waste $(P W)$ as a sole source of carbon for cellulase production by Aspergillus niger strain 13A under submerged and solid-state fermentation. Box-plot (A) illustrated that no significant difference between $K B B$ and $C$ on cellulase production under SmF and Smf, low significant difference * between F and P.P., N.P and CC were outliter. Box-plot (B) illustrated high significant difference ** between SSF and SmF as well as between CMCase and FP-ase productivity under both SSF and SmF. Kraft brown bags (KBB), cardboard $(C)$, foolscap $(F)$, printout paper (P.P) newspapers (N.P) and coated cardboard (C.C)

Kraft brown bags and cardboard contain about 60-70\% cellulose, 10-20\% hemicellulose, and they have a high content of lignin about $5-10 \%$ on the other hand office paper contains about $70 \%$ cellulose and $4 \%$ lignin. Newspaper production is made from paper with high recycled fibre or paper, which contains about $40-55 \%$ cellulose, 25-40\% hemicellulose, and 18-30\% lignin (López Alvarez et al., 2009; 
Gonzalez-Estrella et al., 2017; Li et al., 2020). Although a high cellulose and low lignin content of printing paper and foolscap compared with other type of papers, brown bags and cardboard were found favorable sources of carbon for cellulolytic A. niger strain 13A. These results may be depending on a high lignin content of newspaper and coated cardboard in addition to quantity and type of pigment and ink and other contaminants included with using paper materials. Cummings and Stewart (1994) reported that the presence of ink reduced the rate of cellulose solubilization as well as inhibited the biodegradation process.

The obtained results also showed the highest production of cellulase by A. niger strain 13A was exhibited under SSF compared with SmF for all kinds of paper waste. On the other hand, the CMC-ase production was higher than the FP-ase production for all wastes under both SSF and SmF. SSF has many advantages over SmF such as lowcost, and higher yield of enzymes and productivity, absence of free water and control of bacterial contamination, therefore it is a more suitable technique for the production of fungal enzymes (Bansal et al., 2012; Lodha et al., 2020).

\section{Assay of biocontrol agents}

The experiment between Aspergillus niger strain 13A and Fusarium oxysporum showed noticeable inhibitory effect on the pathogen. The inhibition rate of Aspergillus niger strain 13A ranged from 63.27 to $78.5 \%$.

\section{Biodegradation of paper wastes mixture to produce biomass (bioorganic materials) for the suppression Fusarium wilt in cucumber}

The four best carbon sources of waste paper materials have been mixed well and used as a mass multiplication substrate for A. niger strain 13A to evaluate it is efficacy against the cucumber (Cucumis sativus L.) wilt pathogen. A mixture of waste materials exhibited complete degradation after 42 days and the color of wastepaper mixture was converted to black which is the color of Aspergillus niger; this process produces biomass called bioorganic materials. Under greenhouse conditions, application of the bioorganic materials to soil infested artificially with $F$. oxysporum, Table 4 and Figure 4, exhibited their efficacy to control Fusarium wilt and increased survival of plants.

The results also showed that the use of A. niger-bioorganic materials had demonstrated high efficiency in reducing the disease incidence and disease severity of Fusarium wilt infection. While the incidence and disease severity of $A$. niger-bioorganic materials were $44 \%$ and $26 \%$ respectively, with the efficiency 37.97 and 55.85 , in the control treatment ( $F$. Oxysporum and $F$. oxysporum + untreated mixture) incidence and disease severity were $71.33,60 \%$ and $72,61 \%$, respectively. Sen et al. (1993) and Vibha (2011) reported that A. niger is a potential biocontrol agent for soil borne pathogens. The antagonistic interaction of A. niger with the disease may be due to production of antibiotics, overgrowth and hyper-parasitism. Abed et al. (2019) referred to the use of T. harzianum, T. viride, and Glomus mosseae having a significant effect in reducing the disease incidence of Fusarium wilt of cucumber with the efficiency of 43.54, 39.11 and 65.18\%, respectively. Also, Ahmed (2010) found that Pseudomonas fluorescens No.3 and Serratia marcensens No.2 had completely prevented the Fusarium wilt disease incidence. Compared to the previous reports, A. niger strain $13 \mathrm{~A}$ is considered a promising biological control agent. 
Table 4. Effect of A. niger-bioorganic materials and its efficiency in controlling the Fusarium wilt of cucumber (Cucumis sativus L.)

\begin{tabular}{c|c|c|c|c|c|c|c}
\hline Treatments & $\begin{array}{c}\text { Pre-emergence } \\
\text { damping-off } \\
(\%)\end{array}$ & $\begin{array}{c}\text { Post-emergence } \\
\text { damping-off } \\
(\%)\end{array}$ & $\begin{array}{c}\text { Survival of } \\
\text { plants (\%) }\end{array}$ & $\begin{array}{c}\text { Disease } \\
\text { incidence } \\
(\%)\end{array}$ & $\begin{array}{c}\text { Disease } \\
\text { severity (\%) }\end{array}$ & $\begin{array}{c}\text { Efficiency in } \\
\text { reduction } \\
\text { infection (\%) }\end{array}$ & $\begin{array}{c}\text { Efficiency in } \\
\text { reduction } \\
\text { severity (\%) }\end{array}$ \\
\hline $\begin{array}{c}\text { Control } \\
\text { (uninoculated) }\end{array}$ & $8^{\mathrm{a}}$ & $0^{\mathrm{a}}$ & $92^{\mathrm{a}}$ & 0 & 0 & 0 & 0 \\
\hline F. oxysporum & $25^{\mathrm{c}}$ & $25^{\mathrm{b}}$ & $50^{\mathrm{c}}$ & $71.33^{\mathrm{b}}$ & $60 \mathrm{~b}$ & 0 & 0 \\
\hline $\begin{array}{c}F . \text { oxysporum } \\
+ \text { untreated mixture }\end{array}$ & $25^{\mathrm{c}}$ & $20^{\mathrm{b}}$ & $45^{\mathrm{c}}$ & $72^{\mathrm{a}}$ & $61 \mathrm{a}$ & 0 & 0 \\
\hline $\begin{array}{c}\text { A. niger }+F . \\
\text { Oxysporum }\end{array}$ & $16^{\mathrm{b}}$ & $0^{\mathrm{a}}$ & $84^{\mathrm{b}}$ & $44^{\mathrm{c}}$ & $26 \mathrm{c}$ & 37.97 & 55.85 \\
\hline
\end{tabular}

Values having the same letter within a column are not significantly different according to Duncan multiple range test $(\mathrm{P} \leq 0.05)$. Each number represents an average of three replicates with eight plants in each replicate
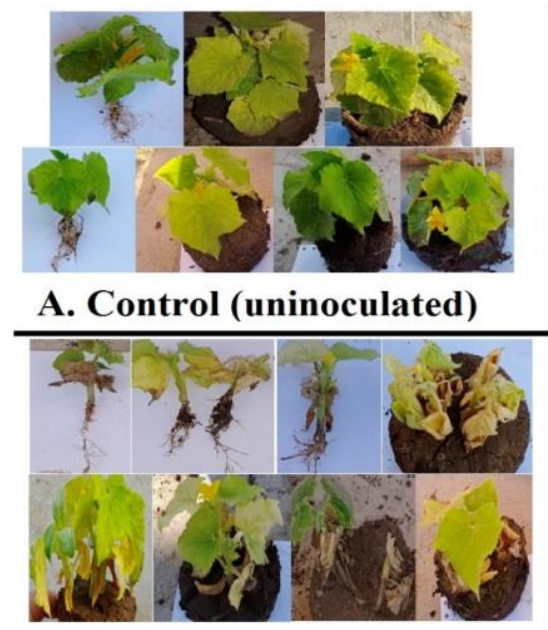

C. F. oxysporum

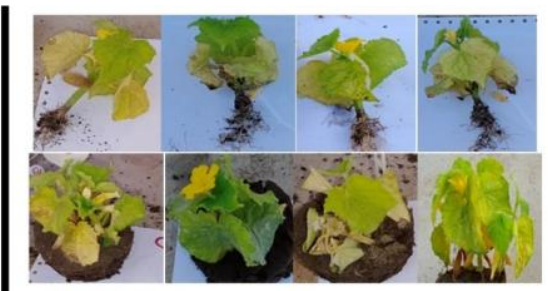

B. Mixture +F. oxysporum

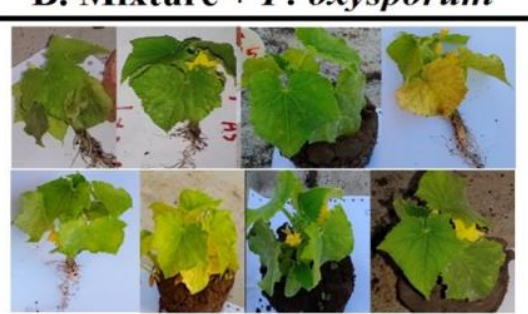

D. A. niger + F. oxysporum

Figure 4. Biocontrol of Fusarium wilt of cucumber by the bioorganic materials

\section{Conclusion}

Successful experiments have been made to convert paper waste (PW) materials into high-value-added products. Kraft brown bags, cardboard, foolscap, printout paper, newspapers and coated cardboard which are some of the paper wastes used in this study as a fermentation substrate produced a good amount of cellulolytic enzyme by Asperigillus niger strain 13A under solid state fermentation. In addition, using A. nigerbioorganic material exhibited efficiency in controlling Fusarium wilt in cucumber. The application of these results may help in limiting the effect of environmental pollution caused by paper waste materials and fungicides.

This study recommends the utilization of paper wastes as a renewable resource of cellulosic constituents to consolidate a cleaner environment and to produce valuable materials. On the other hand, the use of $A$. niger as a biological control agent needs further study and evaluation.

Acknowledgements. The authors gratefully acknowledge Kafr El-sheikh University and Al-Azhar University, Egypt for supporting this work. 


\section{REFERENCES}

[1] Abdullah, J. J., Greetham, D., Pensupa, N., Tucker, G. A., Du, C. (2016): Optimizing cellulase production from municipal solid waste (MSW) using solid state fermentation (SSF). - Journal of Fundamentals of Renewable Energy and Applications 6(3): 1-10.

[2] Abed, J. M., Farhan, T. A., Kadhum, A. A., Abed, M. M., Zaki, N. A., Edbeib, M. F. (2019): Effect of some biocontrol factors and their efficacy in resistance to Fusarium wilt disease caused by Fusarium oxysporum F. sp. Cucumerinum on Cucumber plant under open field conditions. - International Conference on Biosci. and Medi. Engin. AIP Conf. Proc. 2155: 020031-1-020031-5.

[3] Ahmed, G. A. (2010): Controlling of Fusarium wilt of cucumber by antagonistic bacteria. - Journal of Life Sciences 4(7): 16-21.

[4] Baig, S., Saleem, M. (2012): Production and characterization of cellulases of Aspergillus niger by using rice husk and saw dust as substrates. - Pakistan Journal of Botany 44: 377382.

[5] Bansal, N., Tewari, R., Soni, R., Soni, S. K. (2012): Production of cellulases from Aspergillus niger NS-2 in solid state fermentation on agricultural and kitchen waste residues. - Waste Management 32: 1341-1346.

[6] Belal, E. B. A. (2003): Investigation on the biodegradation of polyesters by isolated mesophilic microbes. - Dissertation, Technical University Braunschweig.

[7] Belal, E. B. (2008): Biodegradation of wastepaper by Trichoderma viride and using the bioprocessed materials in biocontrol of damping-off of pea caused by Pythium debaryanum. - J. Agric. Res., Kafrelsheikh Univ. 34(3): 567-587.

[8] Belal, E. B., Gabr, M., El-Gremi, S., Ibrahim, M. E. (1996): Interaction between Antagonistic Microorganisms and certain soil-borne pathogens of soybean in relation to Bradyrhizobium japonicum. - J. Agric. Res. Tanta Univ. 22(4): 451-459.

[9] Benito, C., Figueiras, A., Zaragoza, C., Gallego, F., De La Pena, A. (1993): Rapid identifi-cation of Triticeae genotypes from single seeds using the polymerase chain reaction. - Plant Mol. Biol. 21(1): 181-183.

[10] Cummings, S. P., Stewart, C. S. (1994): Newsparer as substrate for cellulolytic landfill bacteria. - J. Appl. Bacteriol. 76: 196-202.

[11] Cunha, M. N., Esperança, T. C., Zangirolami, A. C., Badino, C. S. (2012): Farinas Sequential solid-state and submerged cultivation of Aspergillus niger on sugarcane bagasse for the production of cellulose. - Bioresource Technology 112: 270-274271.

[12] Dashtban, M., Schraft, H., Qin, W. (2009): Fungal bioconversion of lignocellulosic residues; opportunities \& perspectives. - International Journal of Biological Sciences 5(6): 578.

[13] Dutt, d., Kumar, A. (2014): Optimization of cellulase production under solid-state fermentation by Aspergillus flavus (AT-2) and Aspergillus niger (AT-3) and its impact on stickies and ink particle size of sorted office paper. - Cellulose Chem. Technol. 48: 285298.

[14] Edjabou, M. E., Jensen, M. B., Gotze, R., Pivnenko, K., Petersen, C., Scheutz, C., Astrup, T. F. (2015): Municipal solid waste composition: sampling methodology, statistical analyses, and case study evaluation. - Waste Manag. 36: 12-23.

[15] Eida, M. F., Darwesh, O. M., Matter, I. A. (2018): Cultivation of oleaginous microalgae Scenedesmus obliquus on secondary treated municipal wastewater as growth medium for biodiesel production. - J. Ecol. Engin. 19(5): 38-51.

[16] El-Hassan, S. A., Gowen, S. R. (2006): Formulation and delivery of the bacterial antagonist Bacillus subtilis for management of lentil vascular wilt caused by Fusarium oxysporum f. sp. - lentis. - Phytopathol.154: 148-155.

[17] Ellilä, S., Fonseca, L., Uchima, C., Cota, J., Goldman, G. H., Saloheimo, M., Sacon, V., Siika-aho, M. (2017): Development of a low-cost cellulase production process using 
Trichoderma reesei for Brazilian biorefineries. - Biotechnology for Biofuels 10(30): 117.

[18] Fonoll, X., Astals, S., Dosta, J., Mata-Alvarez, J. (2016): Impact of paper and cardboard suppression on OFMSW anaerobic digestion. - Waste Manag. 56: 100-105.

[19] Ghose, T. K. (1987): Measurement of cellulase activities. - Pure Appl Chem 59: 257-268.

[20] Gonzalez-Estrella, J., Asato, C. M., Jerke, A. C., Stone, J. J., Gilcrease, P. C. (2017): Effect of structural carbohydrates and lignin content on the anaerobic digestion of paper and paper board materials by anaerobic granular sludge. - Biotechnol. Bioeng. 114(5): 951-960.

[21] Imran, M., Anwar, Z., Irshad, M., Asad, M. J., Ashfaq, H. (2016): Cellulase production from species of fungi and bacteria from agricultural wastes and its utilization in industry: a review. - Advances in Enzyme Research 4(2): 44-55.

[22] Joshi, G., Naithani, S., Varshney, V. K., Bisht, S. S., Rana, V. (2017): Potential use of waste paper for the synthesis of cyanoethyl cellulose: a cleaner production approach towards sustainable environment management. - Journal of Cleaner Production 142: 3759-3768.

[23] Juhasz, T., Kozma, K., Szengyel, Z., Reczey, K. (2003): Production of beta glucosidase in mixed culture of Aspergillus niger BKMF 1305 and Trichoderma reesei RUT-C30. Food Technol. Biotechnol. 41: 49-53.

[24] Khan, M. R., Khan, S. M. (2001): Biomanagement of Fusarium wilt of tomato by the soil application for certain phosphorus solubilizing microorganism. - Int J Pest Manag. 47: 227-231.

[25] Khokhar, I., Haider, M. S., Mushtaq, S., Mukhtar, I. (2012): Isolation and screening of highly cellulolytic filamentous fungi. - J. Appl. Sci. Environ. Manage. 16(3): 223 - 226.

[26] Kurup, S. C., Snishamol, R., Nagendra, C., Prabhu, G. (2005): Cellulase production by native bacteria using water hyacinth as substrate under solid state fermentation. - Malay. J Microbiol. 1(2): 25-29.

[27] Lee, S. M., Koo, Y. M. (2001): Pilot-scale production of cellulase using T. reesei rut C30 in fed-batch mode. - J. Microbial Biotechnol. 11: 229- 233.

[28] Li, W., Khalid, H., Amin, F. R., Zhang, H., Dai, Z., Chen, C., Liu, G. (2020): Biomethane production characteristics, kinetic analysis, and energy potential of different paper wastes in anaerobic digestion. - Renewable Energy 157: 1081-1088.

[29] Lodha, A., Pawar, S., Rathod, V. (2020): Optimised cellulase production from fungal coculture of Trichoderma reesei NCIM 1186 and Penicillium citrinum NCIM 768 under solid state fermentation. - Journal of Environmental Chemical Engineering 8: 1-6.

[30] López Alvarez, J. V., Aguilar Larrucea, M., Arraiza Bermúdez, P., León Chicote, B. (2009): Biodegradation of paper waste under controlled composting conditions. - Waste Management 29: 1514-1519.

[31] Lynd, L. R., Weimer, P. J., Van Zy, W. H., Pretorius, I. S. (2002): microbial cellulose utilization: fundamentals and biotechnology. - Microbiol Mol Biolo Reviews 66: 506577.

[32] Martyn, R. D., Stack, J. P. (1990): Biological Control of Soil Borne Plant Pathogens by Antagonistic Fungi. - In: Baudoin, A. B. A. M. (ed.) Laboratory Exercises in Plant Pathology. Scientific Publisher, Jodhpur. pp 64-74.

[33] Miller, G. L. (1959): Use of dinitrosalicylic acid reagent for determination of reducing sugar. - Anal. Chem. 31: 426-429.

[34] Nasr, S., Hussein, N. A., Abozaid, A. A., Al-salemi, F. A. (2011): Cellulose production by two fungal strains isolated from Taif in Saudi Arabia. - J. Agric. Sci. 19(1): 171-178.

[35] Neelamegam, A., Al-Battashi, H., Al-Bahry, S., Nallusamy, S. (2018): Biorefinery production of poly-3-hydroxybutyrate using waste office paper hydrolysate as feedstock for microbial fermentation. - Journal of Biotechnology 265: 25-30.

[36] Ozola, Z. U., Vesere, R., Kalnins, S. N., Blumberga, D. (2019): Paper waste recycling. Circular economy aspects. - Environmental and Climate Technologies 23(3): 260-273. 
[37] Prasanna, H. N., Ramanjaneyulu, G., Rajasekhar, Reddy, B. (2016): Optimization of cellulase production by Penicillium sp. - Biotech. 6(162): 1-11.

[38] Saferi, S.K., Yusof, Y. (2013): A review: natural fiber as reinforcement in waste paper recycling and its processing methods. - Appl. Mech. Mater. 315: 443-447.

[39] Santos, T. C., Arbreu Filho, G., Brito, A. R., Pires, A. J., Bonomo, R. C., Franco, M. (2016): Production and characterization of cellulolytic enzymes by Aspergillus niger and Rhizopus sp. By solid state fermentation of prickly pear. - Revista Caatinga 29: 222-233.

[40] Sen, B., Sharma, J., Asalmol, M. N., Chattopadhyay, C., Patibanda, A. K. (1993): Aspergillus niger - a potential biocontrol agent for soil borne pathogens. - Ind. Phytopath. 46(3): 275-278.

[41] Singhania, R. R., Patel, A. K., Soccol, C. R., Pandey, A. (2009): Recent advances in solid-state fermentation. - Biochemical Engineering Journal 44(1): 13-18.

[42] Sohail, M., Siddiqi, R., Ahmad, A., Khan, S. A. (2009): Cellulase production from Aspergillus niger MS82: effect of temperature and pH. - New Biotechnology 25(6): 437441.

[43] Su, H., Zhu, P., Zhang, L., Zhou, F., Li, G., Li, T., Li, Q., Wang, R., Sun, C., Wong. (2017): Waste to wealth: a sustainable and flexible supercapacitor based on office waste paper electrodes. - Journal of Electroanalytical Chemistry 786: 28-34.

[44] Sukharnikov, L. O., Alahuhta, M., Brunecky, R., Upadhyay, A., Himmel, M. E., Lunin, V. V., Zhulin, I. B. (2012): Sequence, structure, and evolution of cellulases in glycoside hydrolase family 48. - J. Biol. Chem. 287(49): 41068-41077.

[45] Sun, Y., Cheng, J. (2002): Hydrolysis of lignocellulosic materials for ethanol production: a review. - Bioresource Technology 83: 1-11.

[46] Tapwal, A., Sharma, Y. P., Lakhanpal, T. N. (2005): Use of biocontrol agents against white root rot of apple. - J. Mycol. Plant Pathol. 35:67-69.

[47] Teather, R. M., Wood, P. J. (1982): Use of congo red-polysacharide interactions in enumeration and characterization of cellulolytic bacteria in the bovine rumen. - Appl. Environm. Microbiol. 43(4): 777-780.

[48] Toor, Y., Ilyas, U. (2014): Optimization of cellulase production by Aspergillus ornatus by the solid state fermentation of Cicer arietinum. - American Journal of Research 2: 125-141.

[49] Vibha (2011): Evaluation of fungal and bacterial bioagents against Rhizoctonia solani on Solanum melongena L. - Archives of Phytopathology and Plant Protection 44(8): 743750.

[50] Wu, C-c., Cheng, C. (2005): A study of the hydrolysis of waste paper cellulose with a vertically hanging immobilized cellulase reactor and the reuse of the immobilized cellulase. - Journal of the Chinese Chemical Society 52: 85-95 85

[51] Ye, S. F., Yu, J. Q., Peng, Y. H., Zheng, J. H., Zou, Y. (2004): Incidence of Fusarium wilt in Cucumis sativus L. is promoted by cinnamic acid, an autotoxin in root exudates. Plant and Soil 263: 143-150.

[52] Zapata, C. B., Yang, C., Yeh, S., Ogden, J., Kleeman, M. J. (2018): Low-carbon energy generates public health savings in California. - Atmos. Chem. Phys. 18: 4817-4830. 